\title{
SHORTAGE OF ENGINEERS IN THE UNITED STATES
}

$\mathrm{T}$ HE U.S. Engineering Manpower Commission reported that, for the fourth consecutive year, college freshman enrolments in engineering in the autumn of 1961 declined compared with the year before (Interim. Sci. and Tech., February, 1962). The percentage of engineers in the total college population is also declining. In 1957, engineering students numbered $10 \cdot 8$ per cent of the total freshman class; in four years, this has dropped to well below 7 per cent. The result, according to the Commission, is that "the nation will have to make do with fewer engineering graduates for the next four to six years". Engineering graduates have fallen from 52,700 in 1950 to 37,800 in 1960 . It now appears that, by 1965 , the annual total will sink further to some 32,000 .

In contrast, a report from the National Science Foundation indicates that the demand for engineers continues to soar. The American economy requires a little less than a million engineers today : by 1970 this will rise to nearly 1.5 million. To meet this, the annual output of new engineers over the next decade must be 81,000 , or more than twice as many as anticipated.

Why is the engineering manpower supply not keeping pace with the demand? Are increased science enrolments the reason for the slump? Carl Frey, of the Engineering Manpower Commission, states that engineering enrolment actually rose a little-2.5 per cent-in those schools offering both science and engineering, while science enrolments in those schools were up by 24.4 per cent. The 'glamour' sciences are probably drawing away some students who might otherwise have elected to read engineering, but "it hardly seems possible that this alone accounts for the drop in the relative standing of engineering freshmen". The Engineering Manpower Commission report concludes that, "the need is not to take from science and give to engineering, but to increase engineering enrolments while maintaining science at its present level of growth". During the 1960's the Engineering Manpower Commission anticipates that engineering graduates will number about 35,000 annually, while graduates in the sciences, according to estimates by the Natural Science Foundation, will number some 80,000 annually.

If the sciences do not account fully for the slump in engineering, what does? The real cause, according to M. H. Trytten, director of the National Academy of Science, Office of Scientific Personnel, is the inadequate preparation of sufficient young people for careers in engineering: about half the high school students in the United States attend schools which are too small to provide proper training for college work in engineering and science. Trytten believes that the National Science Foundation forecast of the demand for engineers is too conservative, because neither the demands of the space programme nor the need for engineers in the American-sponsored programmes abroad is included in the forecast. "The only way out of the shortage is through stronger programmes of public school preparation 'down into the grades'."

New educational programmes are bringing improvements in the teaching of public school science and mathematics. But Trytten and others, including Prof. J. Conant, insist that these must reach deep into areas of educational neglect such as those now served only by the small rural school and those whose productivity of scientists and engineers is low, particularly in the South. In times when the demands were less severe, these deficiencies were less apparent. With science and technology in such dominant positions in society, there is deep concern that the United States is neglecting the education of one-half of its potential students.

\section{GEOLOGY IN THE U.S.S.R.}

$\mathrm{A}$ CADEMICIAN D. V. NALIVKIN discusses in the October issue of Priroda the future prospects of geological work in the Soviet Union (Priroda, 10, $67 ; 1961)$. He notes the existence of a very large number of geologists carrying out prospecting work for finding new deposits of economic minerals and ores and emphasizes the enormous work done in geological cartography in the production of petrographic, stratigraphic, palæontological, geophysical, metallogenic and other types of maps. For example, palæographical maps will be collected in two large atlases which will be exhibited at the International Geological Congress in India in 1964. Another important feature of Soviet geology is the establishment of fundamental boreholes, aimed at elucidating important geological successions. The author notes four important problems facing the modern Soviet geologist, namely: (1) synthesis of minerals in laboratories and on the industrial scale; (2) problems of tectonics (here he mentions the establishment of a new branch of science-_"astrogeology"-which studies the influence of cosmic factors on terrestrial events); (3) absolute age of sedimentary and igneous rocks, which provides a new ehronological scale in geology; and (4) the problem of the so-called 'underground rocket', a boring apparatus of a new type, which will make possible boring to a depth of $12 \mathrm{~km}$. for the study of the deeper zones of the Earth and for extended prospecting.

Geological age. A new method of determining the age of rocks and meteorites is briefly described by G. F. Komovsky (Priroda, 5, 90; 1961). It is based on the measurement of the relative heights of the peaks of thermoluminescence of rocks heated to $400^{\circ} \mathrm{C}$. This method, however, despite its simplicity, can provide only an approximate date.

Geological folds. Field tectonics and experimental studies lead V. V. Belousov (Priroda, 6, 14; 1961) to postulate the following types of crustal folds: (1) block folds, produced directly by vertical movement of the crust; (2) folds of compression-folds produced in the incompetent (plastic) strata, forming either domes or rolls and due to the attempt to reestablish equilibrium lost during movement of the crust; (3) deep-seated folds, usually occurring in metamorphic or ultra-metamorphic rocks; (4) folds of general compression resulting in widespread linear folds. The general mechanisms of folding are discussed in the article.

Earth's mantle. The project of the study of the Earth's mantle, accepted by the International Union of Geodesy and Geophysics in the summer of 1960 , 
is briefly discussed by V. A. Magnitsky (Priroda, 6, $46 ; 1961$ ). Naturally, this study will be applied only to the upper part of the mantle. A deep boring through the Mohorovičić discontinuity is projected, together with associated seismological, magnitometric, gravimetric and thermal flow studies.

Iron and manganese in ocean deposits. One of the scientific results of the Soviet research vessel Vityaz is the mapping of the concentration of iron-manganese concretions in the deposits of the Pacific Ocean, a brief account of which is given by N. L. Zenkevich and N. S. Skornyakova (Priroda, 2, 47; 1961). The average amount of these concretions in the area of their concentration is 8,600 tons $/ \mathrm{km} .{ }^{2}$. Submarine photographs reveal a very high proportion of the oceanic bottom rich in concretions. These results agree with the findings of $\mathrm{H}$. W. Menard and C. J. Shipek (Nature, 182, 1156; 1958).

Applied geochemistry. Geochemical landscapes, geochemical maps, dispersion aureoles and other problems of applied geochemistry are discussed by A. I. Perel'man (Priroda, 9, 98; 1961) and by A. A. Saukov and A. I. Perel'man (Priroda, 10, 59; 1961). Transformation of a desert. An article by V. N. Kumin (Priroda, 9, 61; 1961) gives a succinct account of the important irrigation scheme encompassed in the construotion of the large Karakum Canal, which carries the waters of the River Amu-Daria over 100,000 hectares of fertile desert lands. Various irrigational and biological problems are discussed.

Paloeoclimatological maps. G. I. Bushinsky (Priroda, 8, 54; 1961) describes palæoclimatological maps constructed on the basis of detailed analysis of lithogenesis by N. M. Strakov, who subdivided lithogenesis into four main types: humid, arid, glacial and volcanological-sedimentary. These types are mapped out on the world map as definite zones for the successive geological periods.

Stromatoliths as indicators of Polar wanderings. A. G. Vologdin (Priroda, 11, 102; 1961) reports that, in collaboration with Chinese geologists, he was able to study in detail stromatoliths (banded algal limestones) of Sinian age (1,200-600 million years) in the region of Zisyan Mountain, 110 miles east-northwest of Peking. It was discovered that these platy formations exhibited on their upper surface convexities which were assumed to be due to the heliotropism of the algae. Previous measurement of the orientation of the convexities of stromatoliths in this region and in the Enisey range showed a displacement of the pole by $40^{\circ}$ during the whole of the Sinian period. This method is considered to be adjunct to the usual palæomagnetic methods in the study of polar migration.
S. T. TOMKEIFFF

\section{EXPORT MARKETING}

$\mathrm{T}$ HE reasons why export marketing has not aroused the same enthusiasm in Britain as in, for example, Germany, the United States, or the U.S.S.R. are discussed in a recent issue of Planning which has been prepared from material supplied by N. A. H. Stacey, economic adviser of the General Electric Co.*.

The relative decline in British exports has often been attributed to the post-war resurgence of Western Germany and Japan, but the report suggests that the length of time which has now elapsed since the end of the Second World War considerably reduces the strength of this contention. Apart from this, two explanations are generally advanced. The first is that Britain has failed to adapt the commodity structure of its exports to changing world needs, and the second that it has failed to adapt its traditional export market pattern to new developments in world trade, in particular to the rapid increase in trade between highly industrialized nations since the War.

Where do the deeper faults lie, and how can they be remedied? The broadsheet coneentrates on what is believed to be one of the major reasons for Britain's lack of success in the world's export markets, namely, the British manufacturer's use of obsolete marketing techniques resulting from a neglect of market research.

The neglect of the marketing function by British industry must be attributed, paradoxically, to the long, unbroken success of British manufacturing industry. Since Britain was the supplier for more than a contury and a half of immense quantities of manufactured goods to the nations of the world, the notion that the process of manufacturing was the foundation of sound business gained an unwarranted sanctity. The corollary to this was the belief that

* Planning, Vol. 28, No. 459 (February 19, 1962): Problems of Txport Marketing. Pn. 19-38. (London: Political and Economic
Thanning, 1062.) 3 s. distribution, even if not unproductive, was not as valuable as manufacturing.

Such an attitude was justified while Britain was the sole mature industrial nation, as it was until the 1880 's. Now it has to share this position with a dozen or more industrial nations. The increased uniformity in the technical performance and efficiency of the goods made by reputable manufacturers in many of the industrial countries has meant that the effort needed for making a sale has assumed much greater importance.

The most important part of successful export effort in the competitive conditions of to-day is sound knowledge of the overseas markets. Familiarity with buyers' requircments, with the needs of the country, the preference of its population, and know. ledge of its recent economic and social development are the determinants of import requirements both to-day and to-morrow. It is part of intelligent marketing to discern requirements and to anticipate needs. Sound marketing is based on the assiduous collection of information to answer two questions. These are: (1) In what (new) markets can the manufacturer sell his existing range of products (with or without modification) or extend his sales? (2) What new products should be made for which there is a demand in his existing markets ?

The neglect of markoting, based on systematic marketing research overseas, is a dominant cause of Britain's present-day export predicament. To find out customers' preferences, to define the characteristics of the market, to estimate the volume of sale, to obtain information on products and prices of the competing manufacturers, to check on the efficiency of publicity, to secure economic information on likely developments in the future, theso uses of marketing research have not been properly considered by many British manufacturers. 